\title{
Strong by concealment? How secrecy, trust, and social embeddedness facilitate corporate crime
}

\author{
J. D. Jaspers ${ }^{1}$ \\ Published online: 11 June 2019 \\ (C) The Author(s) 2019
}

\begin{abstract}
This article examines how corporate crime is organised through studying the longevity of illegal business cartels. Previous studies demonstrate cartels can remain undetected for years or decades. Similar to criminal networks, cartel participants need to communicate in order to collaborate effectively, but operate covertly at the same time. The case study analysis of fourteen Dutch cartel cases in this study demonstrates two main findings. First, cartel participants communicate frequently and elaborately, and the need for trust and communication impedes concealment. Second, the longevity of cartels cannot be explained by isolation from but by embeddedness in their social environment. The context of legitimacy and a facilitating environment are significant factors. Criminal collaboration is studied extensively in literature on organised crime, however gained little attention in the literature on corporate crime. Hereby, this study contributes to an understanding of how corporate criminal conduct is organised, by applying relevant theory on criminal networks gleaned from the literature on organised crime.
\end{abstract}

\section{Introduction}

Criminal acts committed through collaboration between criminal partners require not only concealment but also communication. Communication is essential in organising crime: namely, making arrangements regarding the required resources, contacts and transport; settling disputes; and dividing criminal profits [1]. The balance between operational efficiency through communication and secrecy through concealment is a widely known trade-off for participants of any covert network. The paradox of concealment and communication is a focal point in the study of illegal and criminal networks [2-4]. In the literature, concealment and communication are often presented as opposites, operating as communicating vessels [5-7].

\section{J. D. Jaspers}

jaspers@law.eur.nl

1 Erasmus School of Law, Department of Criminology, Erasmus University Rotterdam, Burgemeester Oudlaan 50, 3000 DR Rotterdam, The Netherlands 
As with any criminal network, business cartels - e.g. price-fixing, bid-rigging - need to coordinate collective actions efficiently by communicating while facing the risk of exposure. Firms have to exchange information on prices, customers, tendering procedures and so on; internal issues and disputes must be resolved; and acceptable agreements on compensations must be reached between participants [8,9]. In light of increasing enforcement efforts and the criminalisation of business cartels [10-12], perpetrators of cartel conduct must also conceal their activities from customers, nonparticipants, and internal and external watchdogs.

Despite the risk of detection, many cartels remain active for years, even decades [13, 14]. For instance, the recent European price-fixing truck cartel lasted for 14 consecutive years (IP/16/2582), and is no exception (cf. [13]). This raises questions as to how business cartels succeed in remaining undetected for long periods, considering the increased pressure on revealing cartel conduct and their need for communication and coordination. Are there effective social control mechanisms within cartels that ensure long-lasting secrecy? Do cartels employ effective modus operandi of concealment? Does a silent or even cooperative social environment ensure cartels of their longevity? Although these are familiar questions with regard to criminal networks, they have received limited attention thus far in the literature on cartels.

Cartels consist of illegal activities in otherwise legal networks [15] and the question as to how cartels deal with communication and secrecy should be addressed accordingly. Considering cartels as communication networks has rarely been done (cf. [6, 8]). Recent studies that do adopt an organised crime perspective regarding the organisation of serious crimes such as fraud and bribery have demonstrated that this provides a fruitful approach for studying corporate and white-collar crime [16-19]. It exposes the nature and structure of these crimes, and sheds light on new criminal opportunities and systematic causes for corporate and white-collar crime. Business cartels can be seen as a form of corporate and thereby organisational crime [20-22] in which legitimate firms, business relations, and transactions provide the context for illegitimate conduct [23, 24]. Business cartels are inherently incorporated in legal networks and legitimate firms [15]. However, earlier studies demonstrate how covertness and secrecy are important dimensions of cartel conduct. Both within and outside companies involved in cartel agreements, covertness is an important aspect (cf. the Vitamins cartel, [25]). This exemplifies how much of what happens in firms is shaped by informal and unwritten processes [26, 27].

Hence, this article applies the criminological notions on the functioning of illegal and criminal networks to the nature and structure of business cartels. First, using these insights - rather than legal and economic theory - enables a broader understanding with regard to the longevity and effective secrecy of cartels. Applying social theory to study corporate crime and in particular cartels enables to reach beyond the idea of both the homo economicus (the rational actor, cf. [28]) and the homo juridicus (the legal actor that knows and recognises the law, cf. [29]) in understanding and explaining cartel conduct. Second, the empirical findings of this article shed new light on the theoretically assumed tension between communication and concealment in illegal networks. By investigating how cartels are organised, this article applies insights gained from extensive study of covert and criminal networks to cartel agreements. Employing that perspective, this study builds upon the work of Levi [18], Passas [30] and Ruggiero [31], where corporate and white-collar crime is studied by examining the mobilisation of existing resources and networks. 


\section{Secrecy and trust in criminal networks}

Two lines of thought within the literature on criminal networks are discussed: one that departs from the concept of the 'secret society' and the trade-off between communication and concealment, and one that focuses on the importance of mutual trust and social networks for operating in illegality. These insights are subsequently translated into expectations regarding cartels.

\section{Criminal networks as secret societies}

Several sociological studies on covert networks and criminal networks like terrorist groups and mafia families depart from a trade-off between communication and concealment $([2-6,32]$, p. $63 ;[7,33])$. These studies employ the classical concept of the secret society as their conceptual point of departure. Networks that maximise for concealment and are strongly isolated from their environment - like Freemasonry or WWII resistance groups - are also characterised as secret societies [34, 35]. Georg Simmel introduced the concept of the secret society as follows: [...] 'an interactional unit characterized in its totality by the fact that reciprocal relations among its members are governed by the protective function of secrecy' [34, 35]. Simmel [35] elaborated on two central circumstances in the secret society: namely, members are concerned with the protection of ideas, objects, activities, and sentiments to which they attach positive value; and members seek protection by controlling the distribution of information about the valued elements. According to Simmel's concept, outside pressure towards certain ideas and activities of a group enhances the likelihood of secret societies forming.

The literature on criminal networks that uses the concept of the secret society describes different examples in which criminal networks deal with the expected trade-off between concealment and communication. One example is the 'Cupola' within the Cosa Nostra. This 'commission' of highly ranked experienced men within the Cosa Nostra was supposedly responsible for internal dispute settlement ([1], p. 61). These men held a key information position regarding the illegal activities of the Cosa Nostra 'family', but were themselves never directly involved in criminal activities. This shielded them from prosecution by the authorities and law enforcement. This example suggests a form of centralisation of communication and information. A second example of how illegal networks deal with the assumed trade-off between communication and concealment are terrorist groups. Terrorist groups are known to operate and communicate through a decentralised cell structure. People within a cell know each other, but do not possess information concerning how the overarching network outside the cell is organised or know the identity of participants of other cells $[3,36]$.

In theory, prioritising either for concealment or for effective communication leads to a different network structure. Prioritising for concealment is expected to lead to a decentralised network, while prioritising for effective communication is expected to lead to a centralised network [6]. Networks that are focused on effective communication leave their participants more vulnerable to detection and punishment. In contrast, networks that are focused on concealment are less successful in generating effective communication, which is detrimental to the network's operational efficiency $[6,37]$. The aspect for which networks prioritise is expected to depend on the need to act and the accompanying need for and frequency of communication [5-7]. This means that 
terrorist groups are more prone to prioritise for concealment than for communication, because they require less continuous action and therefore less communication [7]. Moreover, covert social networks are therefore expected to be project-oriented [38].

In short, decentralised networks provide better protection against detection of its members, while centralised networks provide more effective communication. In light of the literature, it is expected that cartels limit their frequency of communication with regard to their need to operate covertly. The degree of communication within the network is expected to be minimalised, and participants share information only on a need-to-know basis (cf. [33]).

\section{Criminal networks as networks of trust}

For decades, the classic concept of secret societies was also the image that existed of organised crime. Contemporary literature suggests that communication and concealment go hand-in-hand. Instead of a paradox, they are both regarded as imperative to the longevity of criminal networks [39-41]. The classic image of criminal networks as being centralised and hierarchical is also outdated by criminological research into organised crime and has been adjusted to being an image of the flexible criminal 'entrepreneur' [42-45]. Owing to the need to be flexible and secretive, most criminal networks involved in organised crime are unlikely to become large-scale 'enterprises' with a clear structure, hierarchy, and bureaucracy [46]. ${ }^{1}$ Criminal networks are more likely to function horizontally and through means of decentralised communication structures. In these structures trust, again plays an important role.

The literature on organised crime demonstrates how mutual trust is of great importance to the functioning of criminal networks [39-41]. Trust is considered to work in two ways - it is important both for effective communication and for the successful concealment of illegal activities. Indeed, communication is considered a condition for concealment in criminal networks. In this sense, trust functions as a linking pin in the operation of criminal networks. In some contemporary literature, communication and concealment are therefore not considered a trade-off but two equally pivotal imperatives for the functioning of criminal networks. Trust is strongest in pre-existing social relations: namely, strong ties. Therefore, most participants in illegal networks are recruited from existing social networks [47]. Strong social ties, like family ties (cf. [48]), provide trustworthy partners that are discrete towards outsiders with regard to the illegal activities. Unlike conclusions in the literature that are based on the trade-off between communication and concealment, trust can be built through elaborate communication [40, 41]. However, strong ties do also present a possible liability relating to concealment, because potential evidence is scattered when information is exchanged elaborately. Ultimately, trust is a function of expectations, and has to do with building a reputation of trustworthiness [6]. A shared past provides input for this reputation, and a shared future creates the need for it [49].

\footnotetext{
${ }^{1}$ This does not negate the fact that vertically organised hierarchical criminal organisations (e.g. the Cosa Nostra) exist. However, they are neither the only form of organised crime nor do they exclusively control the illegal markets. Paoli states this in her 'paradoxes of organized crime'. One of these paradoxes entails that organisations that are effective in illegal markets, due to their flexible and horizontal structure, are unfit because of their nature to develop into large-scale criminal 'enterprises'.
} 
At the same time, it is important for criminal networks to work not only with trustworthy partners but also with capable partners: namely, people who can provide certain skills, contacts, and resources that are essential to the illegal conduct ([50], p. 51). Therefore, criminal networks also tend to use potential partners outside of their existing social network. This is referred to as the strength of weak ties [51, 52]. Because participants in criminal networks sometimes need to work with these weak ties, they use what is called trust-substitutes - forms of 'hostage-taking' to increase cooperation among co-offenders [53]. When there is a lack of trust in legitimate business relations, parties can use certain securities that increase the costs of opportunistic behaviour, such as contracts with fines or bounties. Within criminal networks, participants rely on alternative resources. One of these resources can be the threat of violence, such as 'hostage-taking' ([50], p. 66; [1, 45, 53]). However, the actual use of violence often appears to be a costly strategy insofar as it attracts unwanted attention from enforcement authorities, which results in caution in applying it $[45,54,55]$. In addition, the use of violence might prevent partners from cheating, but can at the same time result in losing other, potential partners ([1], p. 36).

In short, based on the literature it is expected that cartels focus strongly on effective communication because of the importance of mutual trust, and not primarily on concealment. In addition, cartels are expected to focus on generating mutual trust, and to communicate frequently in order to achieve this goal. Firms within cartels are expected to use existing social ties (strong ties), and also to seek capable business partners with whom they do not have a history of cooperation - and trust (weak ties) - because these ties prove to be essential for establishing specific goals. The use of weak ties leads firms within cartels to make use of trust-substitutes.

\section{Criminal networks and social embeddedness}

The fact that criminal conduct can remain hidden from outsiders might not only be due to the operation of the network itself - it may be explained by the relation of the network to its social environment. Do isolation and covertness truly protect members of criminal networks against detection? Or does it make them more vulnerable to suspicion and detection? An alternative explanation is that neither isolation nor exclusion but the social embeddedness of crime and criminal networks protects its members against detection $[30,56,57]$. Scholars have suggested that most crime is committed within an informed and even cooperative social environment [58, 59]. The embeddedness of illegal activities in legal networks, organisations, and platforms provides a silent social environment that operates as a shell surrounding criminal networks.

In other words, to answer the question how cartels succeed in hiding their activities from outsiders for long periods of time, the relation of the cartel and its participants with their social environment is also important. In the existing literature, the concept of social embeddedness is used to describe this process [51, 52, 57]. Social embeddedness entails both structural and relational embeddedness. It concerns institutional aspects, such as the role of licit organisations, services, and communication platforms, and the function of social relations of criminal network participants with people outside or inside the periphery of this network. Regarding the role of facilitators, social 
embeddedness is discussed extensively in the literature on criminal networks $[60,61]$. Facilitators are considered to be licit actors ${ }^{2}$ that intentionally or unintentionally fulfil a role in the illegal activities of the criminal network: for instance, the role that solicitors and lawyers play in laundering criminal money [62-64], or the role of companies and entrepreneurs in the transport sector in the traffic and trade of illegal goods [39, 65].

\section{Business cartels as criminal networks}

As previously stated, the expectation is that many of the traits, dilemmas, and processes relevant for most illegal and criminal networks contribute to an understanding and an explanation of the operation of business cartels. However, cartels do possess certain particularities that must be addressed. First, because cartels deal with agreements between business competitors, mutual trust and communication are expected to be essential, but are also more problematic for the operation of cartels. Self-interest and opportunism can form challenges for competitors to work together. This raises the question as to whether cartel participants use trust-substitutes, and, if so, in what shape or form do these trust-substitutes occur. Second, cartel conduct entails illegal activities that take place within the normal course of doing business: namely, within licit organisations (cf. [20-22]). Therefore, is it easier to shroud cartel conduct in a sphere of legality (cf. $[23,24,66])$ ?

By now, one could reflect on the question whether the context of, for example, working out misunderstandings within price-fixing cartels could be further away from dealing with conflict over missed payments between hardened drug criminals. The Dutch fruit trader Rinus M. found out about this difference the hard way. When he became involved in transporting illegal drugs and a shipment went missing, he tried to resolve the issue using business mores, but was confronted with those of organised crime: namely, intimidation and eventually assassination (NRC, 16th September 2016). Although there are obvious differences between business cartels and other forms of organised crime, such as the use of violence, this paper argues that it is fruitful to apply insights on criminal cooperation, gained in studies on organised criminal networks, to business cartels. This can help to explain the nature of cartel networks and their longevity, and to provide input with regard to considering enforcement strategies.

In conclusion, a criminal network perspective, including notions of secrecy, trust and social embeddedness, provides several reasons as to why criminal conduct remains hidden from the public for long periods. Three main expectations are: (1) criminal networks may not be as centralised and hierarchically organised as in the classic image of the 'secret society'; (2) criminal networks may not only prioritise for concealment but also for effective communication; (3) it is not isolation from their social environment but their embeddedness that provides an explanation for the longevity of criminal networks.

\footnotetext{
${ }^{2}$ Therefore, although they are not referred to as facilitators for the purpose of this article, illicit actors involved in facilitating crime, such as a hitman or a forger of passports, are sometimes also labelled facilitators in the existing literature $[31,61]$.
} 


\section{Methods and data sources}

This article examines cartel stability based on a qualitative case file analysis of 14 Dutch cases. In these cases, the Dutch Competition Authority imposed an administrative fine between October 2007 and January 2012. ${ }^{3}$ These cases were selected because reports that lead to a fine contain substantial proof, including documentation on coordination and communication within cartels. This documentation allowed for a systematic and in-depth study of the structure and nature of cartels. The cases were examined using document analysis and semi-structured interviews with case managers from the Authority for Consumers and Markets. The sources are official reports by the authority, ${ }^{4}$ summarising the files and containing a selection of evidence used in administrative proceedings towards fines imposed upon corporations. These files contain descriptions of the modus operandi of cartels including: correspondence between their members, transcriptions of verbal interrogations with corporate officials by the competition authority, and sources of cartel administration. These statements are supported by additional written administration.

The material was studied systematically, using a checklist focusing on the modus operandi for concealment; the type of network; the nature of mutual relations; the role of the social environment (e.g. industry associations, customers); and mechanisms for mutual trust. For every case, the document analysis was complemented with a semistructured interview with the project manager of the authority that handled the investigation. In these interviews, the following topics were discussed: the nature of the cartel; the type of network and communication; mechanisms for mutual control and trust; and the role of third parties. These interviews served to provide a better overview of the files and an opportunity to ask additional questions that could not be answered in full through studying the written reports.

The use of secondary sources in this study leads to several limitations. Because of detection and enforcement biases, the cases not necessarily provide a representative image of all cartel conduct in the Netherlands. Some cartels have greater chances of being detected, and cases that involve substantial proof have a higher chance of ultimately resulting in an administrative fine. The statements of corporate officials referred to in this article originate from secondary sources, and therefore might express firms' perspectives, but were originally made in the course of an administrative procedure. Note that one of the formal legal requirements of finding a person or corporation guilty of an infringement is that the effects of the infringement must be 'noticeable' and have a significant effect on the market. This might lead some of the corporate officials to deny the 'real' effect of any agreements made as a legal defence strategy, or to under-report their conduct in general.

\footnotetext{
${ }^{3}$ Commissioning administrative fines is one of the possible sanctions authorised by Dutch competition law (according to Art. 56 lid 1 sub a Mw). Since October 2007, Dutch competition law has allowed the investigation of private property and the possibility of fining natural persons (Kamerstukken I 2006/07, 30,071 , A). October 2007 was the starting point of the analysis for the sake of comparability of the material. January 2012 was indicated as end date because cases usually take several years from the initial investigation until the official sanction. All cases completed by January 2012 have been included.

${ }^{4}$ These files are a result of investigations based on the legal power invested in the Dutch competition authority to interrogate corporate officials and to demand corporate intelligence (Art. 5:16 Awb); to investigate company and private property and administration (Art. 5:15, art. 54, $55 \mathrm{Mw}$ ); and to use leniency requests and other relevant informants and public information.
} 
Table 1 presents descriptive information on the selected cases, including the cartel's duration, ${ }^{5}$ number of firms, and nature of the conduct. ${ }^{6}$ The relatively high number of firms in these cases can be biased due to three main issues. First, cartels with an active industry association have a greater chance of detection. Second, cartels with a more limited number of firms may conspire more effectively, with little chance of detection. Third, an effective cartel may have a self-amplifying effect, as the collusion can offer more firms an opportunity to survive.

The Dutch cases in this study have an average duration of about five years, which is comparable to the typical duration of cartels [14]. The duration shows that firms manage to conceal their cartel for several years, despite the large number of participants. This suggests effective communication, and raises several questions. What are the methods of concealment? How do firms deal in practice with theoretically expected trade-offs between communication and concealment? Which network structure does this result in? And what role do trust, existing networks, and facilitators play?

Table 1 also states the nature of the conduct. Three main categories are distinguished: bid-rigging, price-fixing, and market division or allocation. These categories serve as descriptive labels - based on legal definitions - indicating the main category of the infringement, though these categories are not mutually exclusive per se. Bid-rigging involves firms in a tendering procedure, communicating before the bidding takes place. They divide the work and rotate bids, thereby rigging the procedure. Also known as collusive tendering, this generally involves raising price offers to the buyer. In pricefixing cartels, firms make explicit agreements on the price or surcharge of a particular product or service. Firms use, for instance, minimum pricelists. The other cases involve market division or allocation. In these cartels, firms agree to fix market shares or divide markets into geographical regions.

\section{Results and discussion}

The 14 Dutch cartel cases are discussed in light of the question as to how cartels can remain undetected for long periods, and how participants deal with trust, communication, and concealment. Derived from the literature on illegal and criminal networks, three main theoretical expectations are investigated in relation to cartel conduct and presented accordingly: (1) exchange of information in cartels is not as centralised and hierarchically organised as in the classic image of the 'secret society'; (2) trust enables cooperation in cartels, and participants build this trust through elaborate communication or by using trust-substitutes; (3) it is not the isolation of cartels from their social environment but social embeddedness that provides an explanation for their longevity.

\footnotetext{
${ }^{5}$ To determine the duration of these cartels, the period of continuous infringement stated in the report is used. This also means that the period before the introduction of the Dutch cartel prohibition (January 1998) is not incorporated in determining the duration. This suggests an underestimation of the actual duration of the cartel. This effect is enhanced by the internal selection bias of the competition authority concerning the minimum standards regarding evidence.

${ }^{6}$ In light of confidentiality, the industry in which the cartels took place cannot be indicated per case in Table 1. The cases took place in the following industries; construction (6); heavy industry (3); general services industry (2); forestry (1); waste disposal (1); and financial services (1).
} 
Table 1 Descriptive information on selected cartel cases

\begin{tabular}{lllll}
\hline Case \# & Duration in years & Number of firms & Nature of the conduct & Collective market share \\
\hline Case 1 & 6 & 9 & Market division & $70 \%$ \\
Case 2 & 8 & 9 & Price-fixing & $85-90 \%$ \\
Case 3 & 6 & 8 & Bid-rigging & $60-80 \%$ \\
Case 4 & 6 & 5 & Market division & $60-80 \%$ \\
Case 5 & 6 & 5 & Bid-rigging & - \\
Case 6 & 1 & 9 & Bid-rigging & - \\
Case 7 & 7 & 15 & Market division & $90 \%$ \\
Case 8 & 1 & 2 & Bid-rigging & - \\
Case 9 & 6 & 15 & Market division & $87.3 \%$ \\
Case 10 & 1.5 & 4 & Price-fixing & $58 \%$ \\
Case 11 & 2 & 3 & Bid-rigging & $85-95 \%$ \\
Case 12 & 9 & 14 & Bid-rigging & - \\
Case 13 & 3.5 & 10 & Market allocation & - \\
Case 14 & 11 & 4 & Market allocation & $35-50 \%$ \\
\hline
\end{tabular}

\section{Concealment and communication}

In line with what could be expected from earlier studies into business cartels ([6]; [67]; [23], p. 98), the Dutch cases do show methods of concealment, such as limiting face-to-face interaction and minimising the channels of communication. Examples of this include phased price increases; minimalising the frequency of communication; meetings in neutral locations (i.e. not at the offices or on personal premises of the firms or corporate officials involved); discrete mutual compensations (e.g. in kind, or discounts to supplies); and the use of codes. Some cases involve communication exclusively by phone or in person. Most meetings took place in neutral locations, such as conference rooms, restaurants, hotels and so on. With regard to the meetings in case 2 , the secretary of the cartel stated the following:

'The meetings were held in alternating locations. This would typically not take place at the actual offices of one of the firms'. (2)

In case 8 , one of the cartel participants - in a conversation with his cartel partner - even refers to the risk of communicating over the phone, and stresses the need to meet in person. This episode of a recorded telephone conversation is related to bid-rigging, and is directed at trading information on who takes part in a particular tendering procedure:

'A: Would you be able to drop by the office this morning?

B: Yes, let's see, because tomorrow is the bidding for project of [name of street] right?

A: 4 pm, could you make it?

(...) 
B: Yeah, no, it would be better to meet at yours before, because I also have some background information. I would prefer discussing it with you in private (...)

A: Because, uhm, yes.. around 2 pm, could you make that, or no?

B: Yeah ok, that could work, I will just stick around here in [name city]'.

The cases show that as well as minimalising written communication, cartel participants also try to minimalise communication in general. This is demonstrated by the use of impersonal systems of communication, such as a circulation system by 'taking turns' in bid-rigging cartels (also referred to as 'phases-of-the-moon system'); pre-determined geographical allocations; lists with client distributions; and minimum pricelists. These systems can make abundant personal contact and correspondence superfluous, and can thereby minimise the risk of detection and written evidence at a later stage. However, the paradox here is that building mutual trust, which can be done through extensive and frequent personal communication, is hindered by the use of these impersonal 'buffers' (cf. [37], p. 78).

At the same time - antithetic to the previously mentioned studies - the cases show how cartel participants tend to document a significant part of their agreements and communication. This is demonstrated by elaborate written overviews, individual and collective turnover lists, client lists, minutes of plenary sessions etc. (cf. [56, 68]). This exemplifies that minimalising mutual communication and using impersonal systems of communication is not sufficient for cartels to operate. In particular, the risk of opportunistic behaviour and miscommunication demonstrably leads to frequent communication between cartel participants. A strong illustration of this is the following quote from a secretary of one of the cartels in which he refers to the functioning of instruments such as price lists and the discrepancy between theory and practice:

'The function of a price list is that it indicates the price which others should exceed. Actually, the meetings would have been superfluous if everyone in the cartel would stick to the list. Because it was fixed [...] Word on the street however was that firms would deviate from the agreed upon prices frequently'. (4)

In most cases, effective communication is prioritised over concealment. Case 14, which dealt with a market allocation, also demonstrates this point. The commercial departments of the firms involved in this cartel, which deal with acquiring new customers, had to be brought up to speed on the implications of the cartel agreement (which meant only acquiring customers from their own region). To the question of who was aware of the illegal conduct, the project leader of ACM answered:

'Executives and commercial managers. At the dawn raids in the offices of the firms, maps were seen with a visualisation of the market allocation at the desks of the commercial staff. They were at least required to know the implications of the market allocation agreements when they were on the phone with potential customers. So actually, everyone that was required to be informed, was informed'. (14)

Case 14 clearly illustrates how participants in the cartel exchanged information only on a need-to-know basis (cf. [33]). 
Nevertheless, the need for secrecy in relation to effective communication can indeed result in practical dilemmas. In the operation of case 3, the trade-off between secrecy and operational efficiency is illustrated clearly along with the inherent limitations of maximising covert networks for concealment. The participating firms in case 3 used code names to refer to clients when using the centralised dedicated phone and fax line to communicate on new offers. They employed abbreviations to refer to different municipalities - their clients in this case. In one instance of communication, one firm reported an offer of ' $R$ in NB' and ' $R$ in ZH'. As a result, this caused some confusion among the other firms, with 12 faxes (of questions/answers) exchanged on this issue. There was considerable confusion as to which codes belonged to which municipalities, illustrating how the need for concealment interferes directly with the need for effective communication. In addition, it shows how the need for effective communication prevails over the need for concealment. This can be well understood from a practical viewpoint, since the illegal networks' main goal cannot be achieved without clear communication. In other words, if members of illegal networks fail to understand each other, the whole existence of the network is pointless. These findings hereby contradict the theoretical assumption that illegal networks prioritise for concealment but confirm the expectation that prioritising for effective communication can come at the expense of concealment [6]. The paradox here is that the more one strives for concealment (e.g. by using codes or other impersonal systems of communication), the more frequently one eventually needs to communicate. Also, it concurs well with other studies that show if resources are concentrated amongst a few, the network is likely to be concentrated [38].

\section{The level of centralisation}

The centralised communication system from case 3 is no exception. Noticeably, most of the cases show clear forms of centralisation in the communication structures that are employed by cartel participants. This shows that cartels do not necessarily prioritise for concealment, and that they operate in a highly centralised manner. Illustrative examples include the use of collective summaries and administration of the agreements or third parties that function as secretary or chair of the cartel. This is also demonstrated by case 5 , in which one of the participants discusses the method of communication in the cartel that entails a bid-rigging conspiracy:

'Everyone was audited, it was a form of division of projects [...] We all did our own calculations on the price. No one would accept exceptionally high prices. The coordinator and the one whose turn it was to get the project would debate on the conditions in these general meetings'. (5)

To achieve the cartel's objectives, it appears to be important that the participants communicate frequently and extensively, meet in person, and document their agreements in writing to ensure that participants can take each other at their word. This seems counter-intuitive from a perspective of secrecy, regardless of how collective and plenary communication reveals a pragmatic strategy of cartels in building mutual trust. This seems to be related to the essential role of trust in business cartels, where opportunistic behaviour is a perceived risk with regard to participating firms. Conceptually, however, it remains unclear whether elaborate communication and administration should be perceived as a function of trust or of distrust (cf. [9]). 


\section{The role of trust and trust-substitutes}

Considering the pivotal role that trust plays in cartels, it is unsurprising and in line with the expectations derived from the literature that pre-existing social and professional networks play a significant role in the Dutch cartel cases. Existing ties between competitors, through different platforms within the sector or because firms did business together in the past, can lead to or provide an opportunity for agreements on prices or market division. This confirms the theoretical expectation that having a history of working together strengthens a reputation for being trustworthy (cf. [47]). However, not all cases involve pre-existing relations, or strong ties, between the cartel participants. As well as trustworthy partners, cartel members also need capable partners. As stated earlier, cartels entail agreements between competitors in which the chance for opportunistic behaviour is ever present. Nevertheless, participants in these cartels find solutions for cooperating with weak ties.

As expected from the literature on criminal networks, cartels also have forms of guarantees or 'insurances' against opportunistic behaviour, which can be characterised as trust-substitutes (cf. [53]). First, there are systems of clearing scores (cf. [68, 69]), in which built-up differences between participants are compensated with regard to agreedupon turnover quota, geographical allocation, or client distributions. For this purpose, mutual discounts on supplies, false invoices, or other transactions are used. In addition, in cartels where clients or projects (e.g. bids) are divided or rotated, a common future (referred to as shadow of the future, cf. [49]) also induces mutual trust. A system of reciprocity leads to participants anticipating the work that will come their way in the future. Second, case 9 contains several examples of the use of trustsubstitutes. A relatively large number of firms - 15 - were involved in this case. An example from case 9 is the collective purchase of a bankrupt factory. A large factory, suited for the production of the product involved in the case, came up for sale. The cartel participants were afraid that commissioning the factory by a third party would disturb their conspiracy to control the national market. A third party then purchased the factory on behalf of the cartel, which provided the financial means and instructions for the take-over. The factory was dismantled and the equipment and machines from the factory were divided amongst the participants of the cartel, but - as was discovered later - were never actually put to use. With a provision in the private legal agreement (the purchasing contract), the participants made sure the factory could no longer be used for production of the designated product. The financial investment functioned as a vouch for the market division agreement. Everyone had now invested financial means in a successful execution of the agreement, and had something tangible to lose if it failed.

The role of trust and trust-substitutes is in line with what was expected from the literature on criminal networks. Note, however, that with cartels - and in contrast to some forms of organised crime - trust-substitutes are always - seemingly - legitimate means, such as collective loans, mortgages and so on, which create mutual dependencies and increase the collective interest in the cartel being successful. This makes it all the more difficult for enforcement authorities to detect these legitimate forms of cooperation between firms within the context of illegal cartel conduct. 


\section{Social embeddedness of illegal cartel agreements}

In almost all cases in this study, industry associations and related formal communication platforms play an important role in the cartel. At a minimum, they provide an opportunity for firms in a market to get to know each other, but sometimes these platforms play a more active role. In case 5, firms used a calculation firm as a platform to rig tendering procedures. A calculation firm normally offers consultancy to all companies in the market to measure and calculate the surfaces and equipment needed for a particular project. This way, firms in the sector can share costs of calculation to decrease the losses on calculating projects that they do not get to execute. This is a common and authorised way of doing business. However, the owner of the calculation firm took it one step further by actively hosting illegal cartel meetings between the competitors and documenting their agreements for them. In case 7, the participating firms initially came together to discuss transport safety issues regarding their product. However, prices and clients were also discussed here, resulting in an illegal client distribution between competitors. In case 14, the firms had a 'soft-franchise' system in place. They collectively owned a subsidiary to make legitimate agreements - such as sharing research and development costs - but also made illegal agreements - such as market allocation agreements dividing costumers. The following quote from case 10 illustrates more clearly how industry associations can provide an opportunity for cartel conduct, and can therefore be seen as a form of structural embeddedness of cartels:

'The industry association [A] and industry association [B] served as communication platforms, in which the members would discuss topics that affected the industry as a whole. Topics like pensions, labour conditions and collective employment agreements [...] In between the lines the point was suggested that: 'we should do something about it [the prices]'. (10)

As regards cartel facilitators, intentional and unintentional facilitators can be distinguished. In case 5, for instance, the owner of a calculation firm knowingly and deliberately facilitated cartel conduct. The role that different secretaries and chairmen play in several of the cases can also be seen as deliberately facilitating cartels (e.g. cases 2 and 4). In other cases, clients invited contractors to assess the project on site, which enabled all the requested potential contractors to know which other parties would take part in the tendering procedure. This provided them with an opportunity to rig the procedure, which can be qualified as unintentional facilitation by clients (cases 5 and 7). Clearly, an agreement with a competitor can potentially be made quickly, and many legitimate collaborative platforms and formal meetings can provide an opportunity for cartel conduct to take place.

\section{Discussion}

In short, three main expectations in this study were: (1) cartels may not be as centralised and hierarchically organised as in the classic image of the 'secret society'; (2) cartels may not only prioritise for concealment but also for effective communication; and (3) it is not isolation from their social environment but their (natural) embeddedness that provides an explanation for the longevity of cartels. 
First, to avoid the risk of detection, cartels clearly use techniques aimed at concealing their illegal conduct. However, the case study analysis illustrates how cartel participants are focused primarily on bringing about well-functioning agreements, and they therefore - in a pragmatic manner - communicate frequently and in a centralised manner. Paradoxically, efforts to conceal by means of impersonal communication methods, such as phases-of-the-moon systems (rotating bids by taking turns) and price lists, can lead to a need for more communication and documentation. Cartelists also try to ensure that co-conspirators keep their end of the agreement. Opportunism is perceived a large risk by cartel participants, and increases the need for centralised communication and extensive documentation of agreements. This illustrates how the need for mutual trust often prevails over concealment of conduct by minimising the means of communication. However, further study and discussion is needed to determine whether the elaborate systems of communication and sometimes administration are to be considered instruments for building trust or are in fact indications of the lack of trust.

Second, the use of trust-substitutes and the role of facilitators demonstrate how cartels are strongly embedded in their social environment and can emanate from preexisting professional and personal networks. Cartel participants, in contrast to most 'classic' types of organised criminals, can thereby shroud themselves in a context of legitimate business interactions. The perpetrators of cartel conduct can be considered trusted criminals $[23,24,66]$. Corporate and white-collar crime perpetrators often rise above suspicion, and are facilitated by a cooperative and silent social environment. The position of these perpetrators and the fact that they act on behalf of the organisation particularly in cartels - hereby creates a smokescreen for enforcement authorities, which complicates their detection efforts [56].

Third, this study demonstrates that the longevity of cartel secrecy is explained not so much by concealment or internal control within the cartel as it is by the embeddedness of cartels in their social environment. This is also illustrated by the use of trustsubstitutes (in the form of loans, mortgages, etc.). Furthermore, the role that facilitators play in cartels is made evident from examples of imprudent clients, actively involved secretaries and chairmen of cartels, or - for example - members of collective market associations. The added difficulty in distinguishing the intentional and unintentional facilitation of illegal activities is the distance that exists between the actions of the facilitator and the illegal conduct of the network. This distance provides facilitators with an opportunity to evade moral and legal accountability for their actions (cf. [70]).

\section{Conclusion}

This article explored the organisation of corporate and white-collar crime. This brings up a few points for consideration in the field of both organised and corporate and whitecollar crime. Theoretical implications for the study of corporate crime are that, although one can draw a few parallels in the operation of criminal networks in organised crime (e.g. importance of trust; the use of trust-substitutes; social embeddedness), an important difference lies in the vast opportunities that corporate crime perpetrators have at their disposal to shroud their activities in a context of legitimacy and licit corporate conduct. This might also explain why most organised forms of corporate crime do not 
require types of intimidation or violence in the event of conflict. As regards corporate criminal conduct, an oblivious or cooperative social environment provides practical opportunities for businesses to create and maintain illegal agreements. When it comes to the body of work describing the trade-off between concealment and communication, the theoretical implication for the study of organised crime is that illegal or criminal networks might not always prioritise for concealment. They can operate through elaborate communication and go beyond information exchange on a need-to-know basis, as was demonstrated by the cases described in this analysis.

For the purpose of this study, the role of public regulation and enforcement, or lack thereof, as part of the social environment of cartels was not included. If we would, one may consider the role privatization of regulation and enforcement and cuts of public funding in many regulatory fields in explaining how misconduct can remain hidden in general. However, for the specific area of public anti-cartel enforcement a global rise in public authorities and resources for those authorities has taken place in the past decades [10-12]. In that sense, competition enforcement forms an exception to other regulatory fields, especially in the US, that do suffer privatization and cuts in public funding. This may be connected to the fact that specifically fair competition enforcement endorses and supports the 'neoliberal' ideal of open markets and competition. However, increased resources do not automatically mean increased detection. Also, national governments may increase resources towards enforcement for symbolic reasons that remain separate from questions around enforcement effectiveness regarding detection of cartels.

\section{Policy implications}

It is clear that the longevity cannot be explained solely by studying the means of concealment by cartelists alone. Most cases can be indicated as a 'public secret': namely, many people - within and outside the organisations involved - know or could or should know about the activities, but are either disinterested or are reluctant to come forward to reveal them or to inform enforcement authorities. Governance and regulation of corporate and white-collar crime should pay attention to creating possibilities for gathering the information bystanders have about illegal conduct. Acknowledging the vast amount of knowledge and complicity dispersed in the periphery around illegal networks provides opportunities for detection and enforcement.

Because many licit organisations, platforms, and other facilitators provide opportunities for cartel conduct to occur, it is also important to acknowledge their legal and moral responsibility and accountability with regard to cartels. Some judicial decisions demonstrate how such facilitators can be taken into account [71]. One could argue that governance and regulation of corporate and white-collar crime should examine carefully the responsibility and liability of facilitators and bystanders - as established in efforts against organised crime through criminalising actions of preparation and complicity - (cf. [72]).

This also brings us to lessons learned for operational cartel enforcement. First, cartel participants tend to communicate frequently and in a considerably centralised manner. Episodes of seemingly legitimate transactions or contracts between competitors can therefore be an indication for underlying illegal agreements. In addition, enforcement 
could pay attention to the social embeddedness of cartels through franchise constructions, merger and acquisition processes, market associations, buyers and so on. Deliberately or otherwise, these actors are potential facilitators. By activating the 'silent social environment' to speak up, one can break down walls of secrecy and promote disclosure of misconduct [56]. The Dutch competition authority ACM took certain steps in this area, by launching a public campaign in which more information was presented on the nature and effects of business cartels to create awareness and to motivate the general public to speak up and provide authorities with extra tips and complaints about cartel conduct (Het Financieele Dagblad, 7 June 2016).

Open Access This article is distributed under the terms of the Creative Commons Attribution 4.0 International License (http://creativecommons.org/licenses/by/4.0/), which permits unrestricted use, distribution, and reproduction in any medium, provided you give appropriate credit to the original author(s) and the source, provide a link to the Creative Commons license, and indicate if changes were made.

\section{References}

1. Gambetta, D. (2009). Codes of the underworld: How criminals communicate. Princeton University Press.

2. Kenney, M. (2009). Turning to the 'dark side'. Coordination, exchange, and learning in criminal networks. In M. Kahler (Ed.), Networked politics. Agency, power and governance. London: Cornell University Press.

3. Krebs, V. E. (2002). Mapping networks of terrorist cells. Connections, 24(3), 43-52.

4. Morselli, C. (2009). Inside criminal networks. New York: Springer.

5. Baccara, M., \& Bar-Isaac, H. (2008). How to organize crime. The Review of Economic Studies, 75(4), 1039-1067.

6. Baker, W. E., \& Faulkner, R. R. (1993). The social organization of conspiracy: Illegal networks in the heavy electrical equipment industry. American Sociological Review, 58, 837-860.

7. Morselli, C., Giguère, C., \& Petit, K. (2007). The efficiency/security trade-off in criminal networks. Social Networks, 29(1), 143-153.

8. Faulkner, R. R., Cheney, E. R., Fisher, G. A., \& Baker, W. E. (2003). Crime by committee: Conspirators and company men in the illegal electrical industry cartel, 1954-19591. Criminology, 41(2), 511-554.

9. Jaspers, J. D. (2016). Managing cartels: How cartel participants create stability in the absence of law. European Journal on Criminal Law and Policy.

10. Harding, C., Beaton-Wells, C., Edwards, J. (2015). Leniency and criminal sanctions in anti-cartel enforcement: Happily married or uneasy bedfellows? In: C. Beaton-Wells, \& C. Tran (Eds.). (2015). Anti-cartel enforcement in a contemporary age: Leniency religion. Bloomsbury Publishing.

11. Shaffer, G., \& Nesbitt, N. H. (2011). Criminalizing cartels: A global trend? Sedona Conference Journal, $12,11-26$.

12. Whelan, P. (2014). The criminalization of European cartel enforcement: Theoretical, legal, and practical challenges. Oxford University Press.

13. Connor, J. M. \& Helmers, C. G. (2007). Statistics on modern private international cartels, 1990-2005.

14. Levenstein, M. C., \& Suslow, V. Y. (2006). What determines cartel success? Journal of Economic Literature, XLIV, 43-95.

15. Fear, J. R. (2006). Cartels and competition: Neither markets nor hierarchies. Division of research, Harvard Business School.

16. Edwards, A., \& Levi, M. (2008). Researching the organization of serious crimes. Criminology and Criminal Justice, 8(4), 363-388.

17. Levi, M. (2008a). Organized fraud and organizing frauds unpacking research on networks and organization. Criminology and Criminal Justice, 8(4), 389-419.

18. Levi, M. (2008b). The phantom capitalists: The organization and control of long-firm fraud. Ashgate Publishing, Ltd.

19. Lord, N. \& Levi, M. (2016). Organizing the finances for and the finances from transnational corporate bribery. European Journal of Criminology, 1477370816661740. 
20. Braithwaite, J. (1989). Criminological theory and organizational crime. Justice Quarterly, 6(3), 333-358.

21. Clinard, M. B., \& Yeager, P. C. (1980). Corporate crime. New York: Free Press.

22. Jamieson, K. M. (1994). The organization of corporate crime: Dynamics of antitrust violation. Thousand Oaks: Sage.

23. Punch, M. (1996). Dirty business: Exploring corporate misconduct: Analysis and cases. London: Sage.

24. Wheeler, S., \& Rothman, M. L. (1982). The organization as weapon in white-collar crime. Michigan Law Review, 80(7), 1403-1426.

25. Connor, J.M. (2006). The great global vitamins conspiracy: Sanctions and deterrence. American Antitrust Institute Working Paper No. 06-02. https://doi.org/10.2139/ssrn.1103604.

26. Costas, J., \& Grey, C. (2014). Bringing secrecy into the open: Towards a theorization of the social processes of organizational secrecy. Organization Studies, 35(10), 1423-1447.

27. Parker, M. (2016). Secret societies: Intimations of organization. Organization Studies, 37(1), 99-113.

28. Parker, C. (2012). Economic rationalities of governance and ambiguity in the criminalization of cartels. British Journal of Criminology, 52(5), 974-996.

29. Haines, F., \& Beaton-Wells, C. (2012). Ambiguities in criminalizing cartels a political economy. British Journal of Criminology, 52, 953-973.

30. Passas, N. (2003). Cross-border crime and the Interface between legal and illegal actors. Security Journal, 16(1), 19-38.

31. Ruggiero, V. (1996). Organized and corporate crime in Europe: offers that can't be refused: Dartmouth.

32. Chen, A. (2005). Secret societies and organized crime in contemporary China. Modern Asian Studies, 39(01), 77-107.

33. Zhang, S., \& Chin, K. L. (2002). Enter the dragon: Inside Chinese human smuggling organizations. Criminology, 40(4), 737-768.

34. Hazelrigg, L. E. (1969). A reexamination of Simmel's "the secret and the secret society": Nine propositions. Social Forces, 47(3), 323-330.

35. Simmel, G. (1906). The sociology of secrecy and of secret societies. The American Journal of Sociology, 11(4), 441-498.

36. Memon, N., Larsen, H., Hicks, D., \& Harkiolakis, N. (2008). Detecting hidden hierarchy in terrorist networks: Some case studies. Intelligence and Security Informatics, 477-489.

37. Goffman, E. (1970). Strategic interaction (Vol. 1). University of Pennsylvania Press.

38. Fielding, N. G. (2016). The shaping of covert social networks: Isolating the effects of secrecy. Trends in Organized Crime, 1-15.

39. Kleemans, E. R., \& de Poot, C. J. (2008). Criminal careers in organized crime and social opportunity structure. European Journal of Criminology, 5(1), 69-98.

40. Klerks, P. (2001). The network paradigm applied to criminal organizations: Theoretical nitpicking or a relevant doctrine for investigators? Recent developments in the Netherlands. Connections, 24(3), 53-65.

41. Von Lampe, K., \& Ole Johansen, P. (2004). Organized crime and trust: On the conceptualization and empirical relevance of trust in the context of criminal networks. Global Crime, 6(2), 159-184.

42. Paoli, L., \& Vander Beken, T. (2014). Organized crime: A contested concept. In L. Paoli (Ed.), The Oxford handbook of organized crime. New York: Oxford University Press.

43. Spapens, T. (2010). Macro networks, collectives, and business processes: An integrated approach to organized crime. European Journal of Crime Criminal Law \& Criminal Justice, 18, 185-215.

44. Zaitch, D. (2002). Trafficking cocaine: Colombian drug entrepreneurs in the Netherlands. Den Haag. Kluwer Law International.

45. Zaitch, D. (2005). The ambiguity of violence, secrecy, and trust among Colombian drug entrepreneurs. Journal of Drug Issues, 35(1), 201-228.

46. Paoli, L. (2002). The paradoxes of organized crime. Crime, Law and Social Change, 37(1), 51-97.

47. Erickson, B. H. (1981). Secret societies and social structure. Social Forces, 60(1), 188-210.

48. Moors, H. \& Spapens, T. (2016). Criminele families in Noord-Brabant. Een verkenning van generatieeffecten in de georganiseerde misdaad. Den Haag: Politie en Wetenschap.

49. Kleemans, E. R., \& Van de Bunt, H. G. (1999). The social embeddedness of organized crime. Transnational Organized Crime, 5(1), 19-36.

50. Van de Bunt, H. G., \& Kleemans, E. R. (2007). Georganiseerde criminaliteit in Nederland. Derde rapportage op basis van de Monitor Georganiseerde Criminaliteit. Boom Juridische Uitgevers.

51. Granovetter, M. S. (1973). The strength of weak ties. American Journal of Sociology, 78, 1360-1380.

52. Granovetter, M. (1981). The strength of weak ties: A network theory revisited. New York: State University of New York, Department of Sociology.

53. Campana, P., \& Varese, F. (2013). Cooperation in criminal organizations: Kinship and violence as credible commitments. Rationality and Society, 25(3), 263-289. 
54. Jacques, S., \& Wright, R. (2008). The relevance of peace to studies of drug market violence. Criminology, 46(1), 221-254.

55. Jacques, S., \& Wright, R. (2011). Informal control and illicit drug trade. Criminology, 49(3), 729-765.

56. van de Bunt, H. G. (2010). Walls of secrecy and silence. The Madoff case and cartels in the construction industry. Criminology \& Public Policy, 9(3), 435-453.

57. van de Bunt, H. G., Siegel, D., \& Zaitch, D. (2014). The social embeddedness of organized crime. In L. Paoli (Ed.), (2014). The Oxford handbook of organized crime. New York: Oxford University Press.

58. Gibson, D. R. (2014). Enduring illusions the social organization of secrecy and deception. Sociological Theory, 32(4), 283-306.

59. Hallsworth, S., \& Young, T. (2008). Crime and silence: 'Death and life are in the power of the tongue' (proverbs 18: 21). Theoretical Criminology, 12(2), 131-152.

60. Kleemans, E., \& Van de Bunt, H. G. (2003). The social organisation of human trafficking. In Global organized crime (pp. 97-104). Netherlands: Springer.

61. Morselli, C., \& Giguère, C. (2006). Legitimate strengths in criminal networks. Crime, Law and Social Change, 45(3), 185-200.

62. Di Nicola, A., \& Zoffi, P. (2005). Italian lawyers and criminal clients. Risks and countermeasures. Crime, Law and Social Change, 42(2), 201-225.

63. Lankhorst, F., \& Nelen, H. (2005). Professional services and organised crime in the Netherlands. Crime, Law and Social Change, 42(2), 163-188.

64. Middleton, D. J., \& Levi, M. (2005). The role of solicitors in facilitating 'organized crime': Situational crime opportunities and their regulation. Crime, Law and Social Change, 42(2-3), 123-161.

65. Van Koppen, M. V., \& De Poot, C. J. (2013). The truck driver who bought a café: Offenders on their involvement mechanisms for organized crime. European Journal of Criminology, 10, 74-88.

66. Friedrichs, D. O. (2010). Trusted criminals, white collar crime in contemporary society. Belmont: Wadsworth.

67. Geis, G. (1987). White Collar Crime: The Heavy Electrical Equipment Antitrust Cases of 1961. In: M.D. Ermann \& R.J. Lundmann (Eds.) Corporate and Governmental Deviance: Problems of Organizational Behavior in Contemporary Society. New York: Oxford University Press, p. 111-130.

68. Hertogh, M. L. M. (2010). Crime and custom in the Dutch construction industry. Legisprudence, 4(3), 307-326.

69. van de Bunt, H. G. (2008). Rekeningen vereffenen in de bouw. Tijdschrift voor Criminologie, 51(2), 4.

70. Cohen, S. (2001). States of denial: Knowing about atrocities and suffering. Malden: Blackwell Publishers.

71. Harding, C. (2009). Capturing the cartel's friends: Cartel facilitation and the idea of joint criminal enterprise. European Law Review, 34(2), 298-309.

72. Middleton, D. J. (2005). The legal and regulatory response to solicitors involved in serious fraud is regulatory action more effective than criminal prosecution? British Journal of Criminology, $45(6), 810-836$.

\section{Newspapers}

Het Financieele Dagblad 'ACM roept burgers op kartels te melden'. Source: http://fd.nl/economiepolitiek/1155032/acm-lanceert-publiekscampagne-tegen-verboden-kartelafspraken.

Het NRC Handelsblad 'Hoe een lading cocaïne Rinus fataal werd'. Source: https://www.nrc.nl/nieuws/2016 /09/16/hoe-een-lading-cocaine-rinus-fataal-werd-4319184-a1521850

Publisher's note Springer Nature remains neutral with regard to jurisdictional claims in published maps and institutional affiliations. 